\title{
Modernist bir yapı örneği, Çorlu Belediye Sarayı
}

\author{
Ayşe DURUKAN KOPUZ* \\ Namık Kemal Üniversitesi, Çorlu Müh. Fakültesi \\ Geliş Tarihi (Recived Date): 19.06.2017 \\ Kabul Tarihi (Accepted Date): 25.08.2017
}

\section{Özet}

Türkiye'de modern mimarlı tarihi okumaları çoğunlukla Erken Cumhuriyet Dönemi olarak adlandırılan 1930'lu yıllar üzerinden yapılmaktadır. Bu durum Cumhuriyet'in modernleşme projesi çerçevesinde gerçekleştirilen modern mimarlık yapılarının o yıllarda ortaya koyulmasından kaynaklanır. Ancak bu dönemde yetişmiş ve uzun yıllar mimarlık pratiğine katkıda bulunmuş sayılı mimarlar da yer almaktadır. Bu mimarlar tarafindan gerçekleştirilen, yakın geçmişimize ait modern mimarlık örnekleri de mimarlı tarihi okumalarını derinleştiren ve zenginleştiren önemli veriler sağlamaktadır. Bu noktadan hareketle, Cumhuriyet döneminde yetişmiş ve ürün vermis mimarların, modernist çizgilerini kaybetmeden, daha sonraki yıllarda yapmış oldukları çalışmaları da araştırılmaya değer bir çizgi sunmaktadır.

Sözkonusu dönem tarih yazımında, Altan Ergut'un belirttiği, "çoğunlukla önemli mimarların yaptığı önemli mimari eserler üzerinden okumaların yapıldı̆̆ını" vurgulaması dikkat çekicidir [1]. Mimarları belli olan ve modern mimarlı ürünlerine ait belli yapıların incelenmesi bu açıdan döneme ait bir katkı sağlamaktadır. Bu bakış açısıyla, bu makalede modern mimarlık tarihine katkıda bulunmak amacıyla, 1940-1990 yılları arası dönemine ışı tutan Mimar Maruf Önal'ın, Mimar Hakkı Önel ile tasarladı̆̆ "Çorlu Belediye Sarayı" yapısını tanıtmak ve o dönem için bir değerlendirme yapmak hedeflenmiştir.

Bu anlamda, mimarlı̆̆ın çok boyutlu çerçevesine yaptı̆̆g katkılarıyla çok yönlü bir mimar olarak tanınan Maruf Önal'ın mimarlık yazınına çok sayıda katkıları bulunmuştur. Önal, yapılarında sürekli kendini geliştiren, duyarlı, yere ve zamana bağlı olarak, farklı şehirlerde kalıcı eserler bırakmış nâdir mimarlardan biridir. Özellikle son yıllarda ve büyük şehirlerde, yakın tarihimize ait bu yapıların bir çoğunun yıkılması veya diğerlerinin tehdit altında olması, bu konunun önemini daha da arttırmaktadır. Bu nedenle bu tip yapıların ortaya koyulmasının modern mimarlı ürünlerinin belgelenmesi açısından katkı sağlayacă̆ı düşünülmektedir.

Anahtar Kelimeler: Çorlu belediye sarayı, Maruf Önal, Çorlu, belediye binaları.

\footnotetext{
*Ayşe DURUKAN KOPUZ, akopuz@nku.edu.tr, http://orcid.org/0000-0003-0389-8146
} 


\title{
A modernist building sample, Corlu Municipality Palace
}

\begin{abstract}
The history of Modern Architecture in Turkey is mostly based on the 1930s, which is called the Early Republican Period. This situation arises from the fact that modern architectural structures realized within the framework of the project of modernization of the Republic were revealed in those years. However, architects who were trained in this period and contributed to architectural practice for many years are also included. The recent examples of modern architecture by these architects also provide important data that deepens and enriches the reading of architectural history. From this point on, the works of the architects who have grown and produced in the Republican era, without losing the modernist lines, offer a searchable line of work in the future.

It is noteworthy that Altan Ergut's emphasis on the reading of important architectural works done by important architects in the period writing of the period is remarkable. [1] From this point of view, it was aimed to contribute to the history of modern architecture, to introduce the structure of "Corlu Municipality Palace" designed by Architect Maruf Önal, who sheds light on 1940-1990 period, and to make an evaluation for that period.

Maruf Önal, who is known as a versatile architect with the contributions he made to the multidimensional frame of architecture, has contributed a lot to the architecture literature. Önal is one of the few architects who constantly develop themselves in their structures, sensitive, who have left permanent works in different cities depending on time and time. Especially recently, the necessity of protecting these buildings belonging to our recent history is emphasized, which further increases its importance. That is why it is thought that taking a holistic approach to Çorlu Municipality Palace will contribute to the field of architecture.
\end{abstract}

Keywords: Çorlu municipality palace, Maruf Önal, Çorlu, municipality buildings.

\section{Giriş}

Türkiye'de bir çok kentte, mimarlık uygulamalarına kronolojik olarak baktığımızda, 80'li yılların bir dönüm noktası olduğunu görürüz. Bu yıllar, tüm dünyada ekonomik ve toplumsal politikalardaki neoliberal yaklaşım ve uygulamaların olumlu/olumsuz yönleriyle yaşandığı, Türkiye'de de kullanılan tanımıyla değişim yıllarını tarifler. Söz konusu dönemde, gündelik hayatın dili, mekânsal karakteri ve buna bağlı olarak kentin anlamı değişmiş ve bu değişimin sahnelendiği mekânların sayısı hızla artmıştır. $\mathrm{Bu}$ anlamda, kentsel söylemlerin ve mekânsal referansların tarihçelerine baktığımızda 80’li yıllar bir eşik olarak önümüzde durur [2].

Aslında kentsel söylemin oluşumunda yeni yapı tiplerinin oluşumu, fiziksel değişimlerin kenti dönüştürme amacındaki çabaları, o dönemin bir eşik olarak tariflenmesini mümkün kılmaktadır. Özellikle 80’lerin öne çıkan mekân kurucu pratiklerinden olan kamu yapıları, içerisinde bulundurduğu yeni mekânsal düzenlemelerle karşımıza çıkmaktadır. Bu kamu yapılarından biri olan belediye 
binaları çevreleri ve iç mekân düzenlemelerinde yer alan sanat, gösteri/tiyatro sahneleri ile birlikte yeni bir mekânsal düzenlemeye işaret etmektedir. Bu yazıda, sözkonusu yapılardan biri olan ve 80'li yıllarda Çorlu kentinde inşa edilen belediye binasının, fonksiyon ve cephe olarak modern mimarlık öğretilerine uygun mimarisi, bütüncül bir yaklaşımla tanıtılması hedeflenmektedir.

\section{Materyal ve metod}

Çalışmada, Çorlu kentinde bulunan belediye yapısının incelenmesinde, bina ve çevresinde yerinde gözlem yapılarak, detaylı fotoğraflar çekilmiş, bina iç ve dıș mimarisi hakkında belgeler oluşturulmuştur. Ayrıca yapının yapım aşaması hakkında belediye eski çalışanlarından bilgi alınmış ve belediye arşivinden yapı ile ilgili dokümanlar (projeler ve eski fotoğraflar) elde edilmiştir.

\section{3. Çorlu belediye binası ve yapım süreci}

Trakya Bölgesinde yer alan Çorlu kenti, bugün 250.000 nüfusuyla bir çok il ve ilçeden daha kalabalık bir nüfusa sahiptir. Avrupa'ya geçiş yolu üzerinde olması ve İstanbul'a yakınlığı dolayısıyla bir çok insanın uğrak yeri olmaktadır. Tarihte, 1912-13 Balkan savaşlarında Osmanlı Ordusu Kumandanlığı karargahının buraya kurulmasıyla beraber, 1912'de Bulgarların eline geçen Çorlu, 1913'de kurtarılır. Bu kent, 1920'de Yunan işgaline uğrar ve Trakya'nın kurtuluş mücadelesi buradan yönetilir. Trakya Paşaeli Müdafaa-i Hukuk Cemiyeti'nin kurduğu çeteler, burada faaliyetlerine devam eder. 1922'de savaşılmadan Yunan yönetimi tarafından Türk yönetimine devredilir. Çorlu, İkinci Dünya savaşından beri savunma bakımından önemli bir garnizon olma özelliğini bugün hâlâ korumaktadır [3].

Kent özellikle 1980'li yıllardan sonra, sanayinin bu bölgeye aktarımıyla birlikte hem ekonomik, hem de göç anlamında hızlı bir büyüme gösterir. Sanayinin yaygınlaşması, giderek artan sosyo-kültürel, ekonomik ve teknolojik gelişmeler mimarlık ortamını da etkilemiş ve kente yeni bir belediye binası yapımına karar verilmiştir. Belediye başkanı Seyfettin Meriç döneminde, "Yıldız Üniversitesi Döner Sermaye İşletmesi" tarafından belediye için projelerin yapılması teklif edilir ve 1984 yılı Şubat ayında projeler tamamlanır. Proje çalışma grubunda yer alan, Prof. Maruf Önal (1918-2010), Doç. Hakkı Önel (1948-2013), Doç. Ali Düzgün ve Öğr. Gör. Radi Birol tarafından "Çorlu Belediye Sarayı" tasarlanıp ardından inşa edilir.

Başlıca mimarlardan olan Maruf Önal'ın, mimarlık alanına hem uygulama hemde eğitim alanında yaptığı katkılar çok dikkate değerdir. Uzun yıllar Yıldız Üniversite'sinde öğretim üyeliği yapmış bunun yanısıra bir çok konut yapısı (Basın sitesi, Belen evi, Ar apartmanı, Veziroğlu villası, Dostlar sitesi, Külte evi), banka şubeleri (Etibank Karaköy şubesi, Ziraat Bankası Bakırköy şubesi, oteller, petrol istasyonları tasarlamış ve bir çok yarışmaya (Ankara- Antalya İmar Planı ve Şehircilik yarışması, Sakarya Hükümet Konağı yarışması, İstanbul radyo evi yarışması, İstanbul Adalet sarayı yarışması) katılmıştır [4].

Çorlu belediye binası da, modern bir üslub doğrultusunda, bir kamu yapısı olmasına rağmen, mütevazı ve rasyonel bir yaklaşımla tasarlanarak, özenli bir yapımla 
gerçekleştirilmiştir. Binanın hafriyat ve yapım aşamasında çekilmiş fotoğrafları hem inşaat kalitesini hem de o dönem yapının çevresinin niteliğini gösterir niteliktedir. $($ Resim 1).
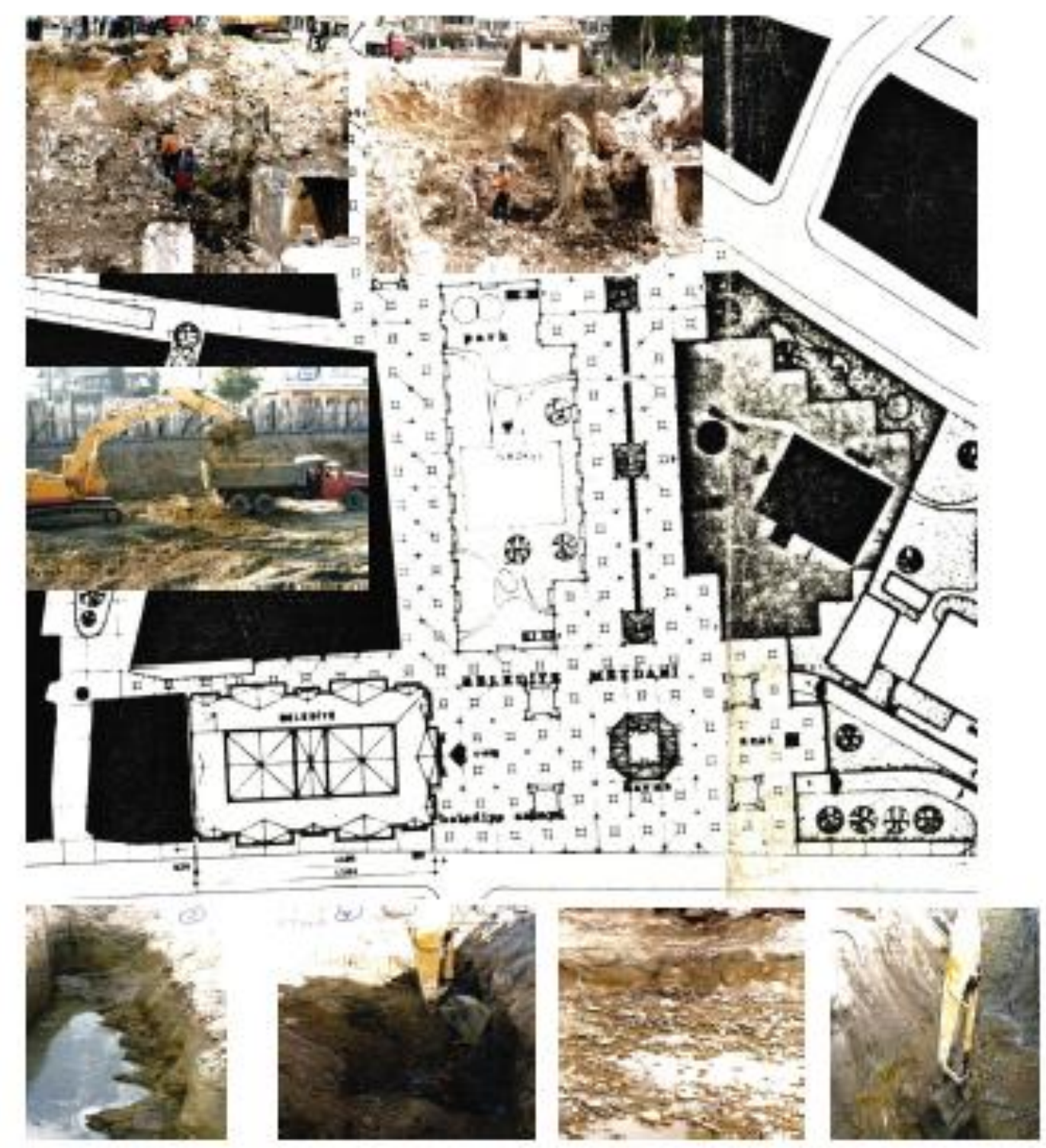

Resim 1. Belediye binası inşaat başlangıcında görünümler (Çorlu belediye arşivi).

Konum olarak, belediye sarayı, Salih Omurtak caddesinin yeni açıldığ dönemde, Kumyol caddesi ve Omurtak caddesi arasında, Çorlu'da yapılaşmanın henüz yoğunlaşmadığı yıllarda (bu binanın yapımından sonra büyük bir hız kazanmıştır), bugünkü Cumhuriyet meydanının önünde inşa edilmiştir. Proje alanında, 1936 yılında yapılan Sücaettin ilkokulu binası ve Çorlu belediyesine ait eski betonarme hamam ve sarnıçların yıkılarak yerine belediye sarayının yapımına karar verilmiş ve belediye binası önündeki meydanla bu alana yerleştirilmiştir (Resim 2,3). Çevresinde 1930'lu yıllarda inşa edilen, Askeri Hastane, Orduevi ve 5. Kolordu Komutanlığ binaları yer almaktadır. Kamu yapılarının yer aldığı eski şehir merkezinde yer alacak yapı, güney tarafı cadde, kuzey bölümü büyük bir meydan olarak tasarlanmıştır. 

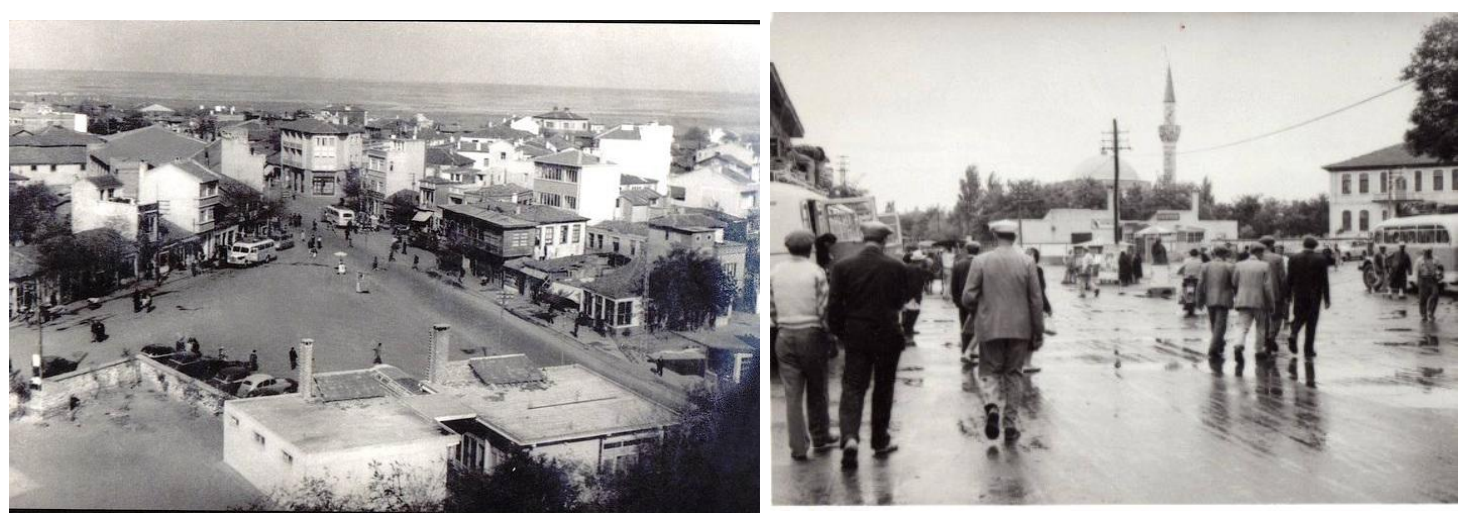

Resim 2. Belediye binasının yapılacağı alan ve Cumhuriyet Meydanı, 1970’ler (Kerem Savaş arşivi).
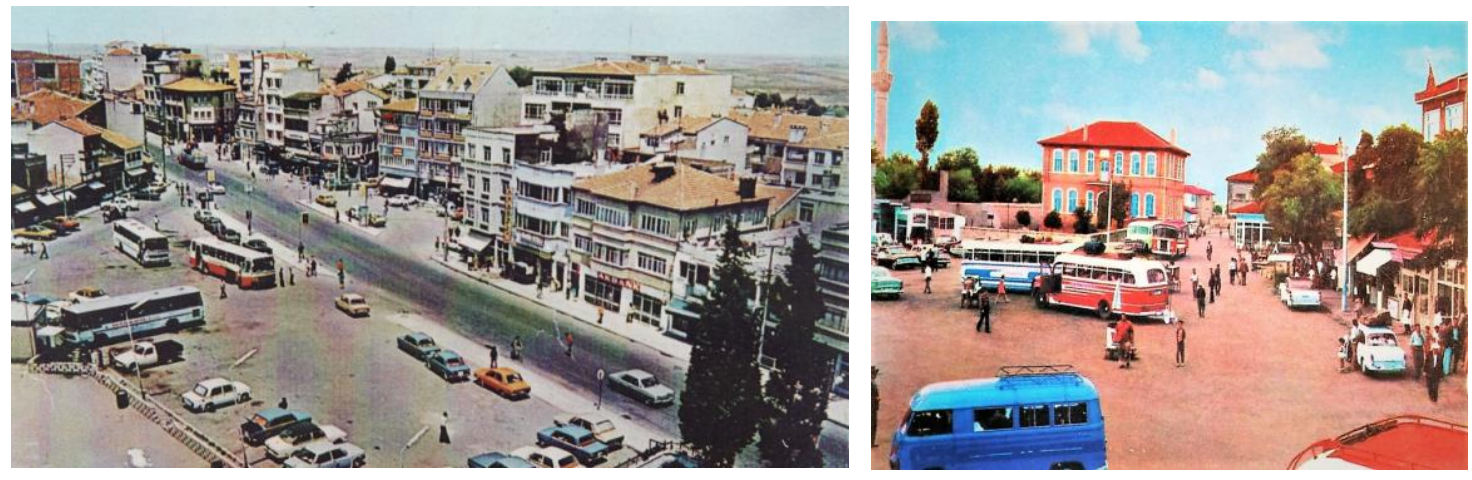

Resim 3. Cumhuriyet meydanı ve Şücaeetin İlkokulu, 1970’ler (Kerem Savaş arşivi).

Yapının projeleri 1984 yılında tamamlanmış, 1986 yılında da binanın inşaatına başlanmıştır. Ancak Önal ve arkadaşlarının çizdiği yapının yer alacağı alanda, yapılan hafriyat sırasında temel suyu, \%50 küskü, \%50 balçık ve batak karışımı yumuşak kaya çıktığ 1 (Resim 4) için binanın yeri projedeki gibi yerleştirilmemiştir. Proje alanının yeri değiştirilerek eski hamamın olduğu yere, dar cephesi ve girişi kuzeye gelecek şekilde konumlandırılmıştır (Resim 5).

Burada vurgulanması gereken bir nokta ise, 2007 y1lında Çorlu Belediyesi bu binadan ayrılarak Tekirdağ yolu üzerinde yeni binasına taşınmış ancak halktan ve kullanıcılardan gelen yoğun taleb üzerine 2010 Kasım ayında tekrardan merkezde yer alan bu binaya geçmişlerdir.

Belediye sarayı, mevcut koşullara ve bulunduğu lokasyana uyan, binanın fonksiyonlarına akılcı bir şekilde cevap veren, özgün ve nitelikli plan ve cephe kurgusuyla modern bir mimari dile sahiptir. Bu anlamda yapının kütle, plan cephe kurguları olarak değerlendirilmesi, dönemin mimari anlayışı hakkında ipuçları sunar. 


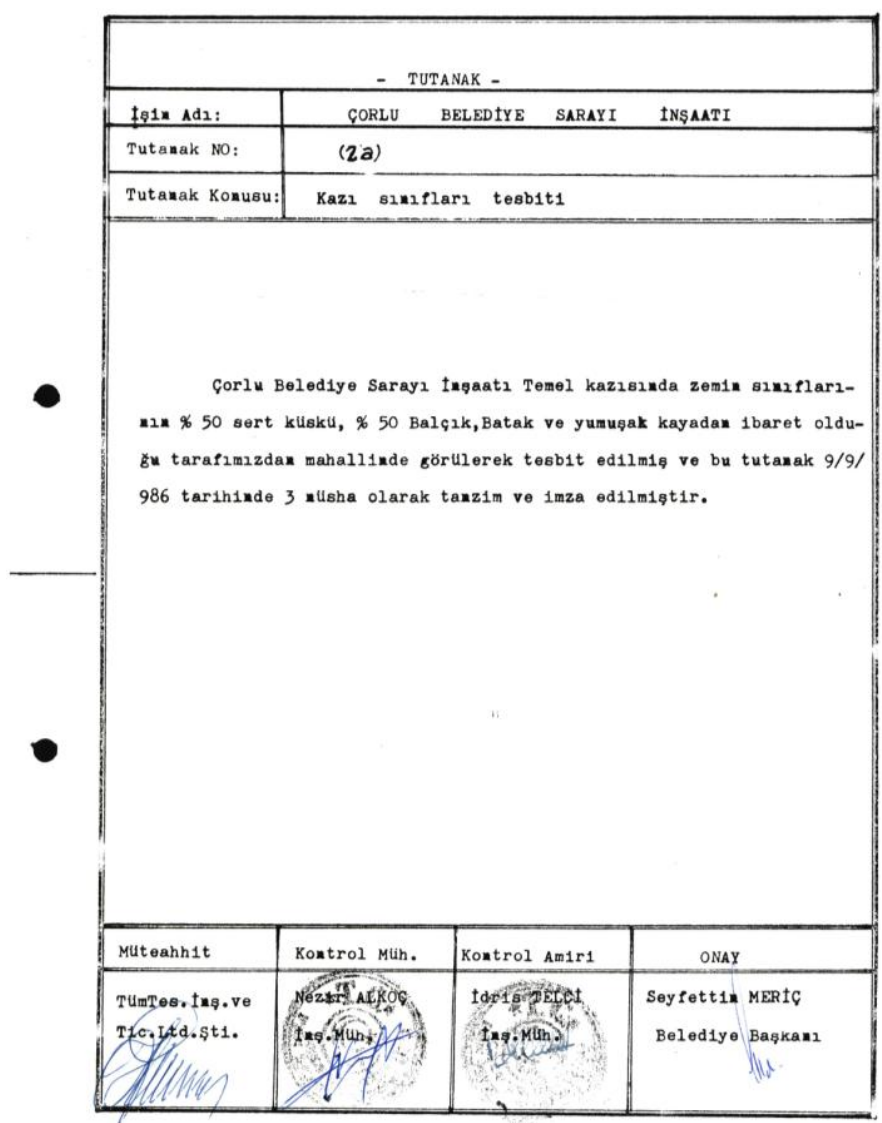

Resim 4. Bina hafriyat aşamasında tutulan tutanak (Çorlu Belediye Arşivi).

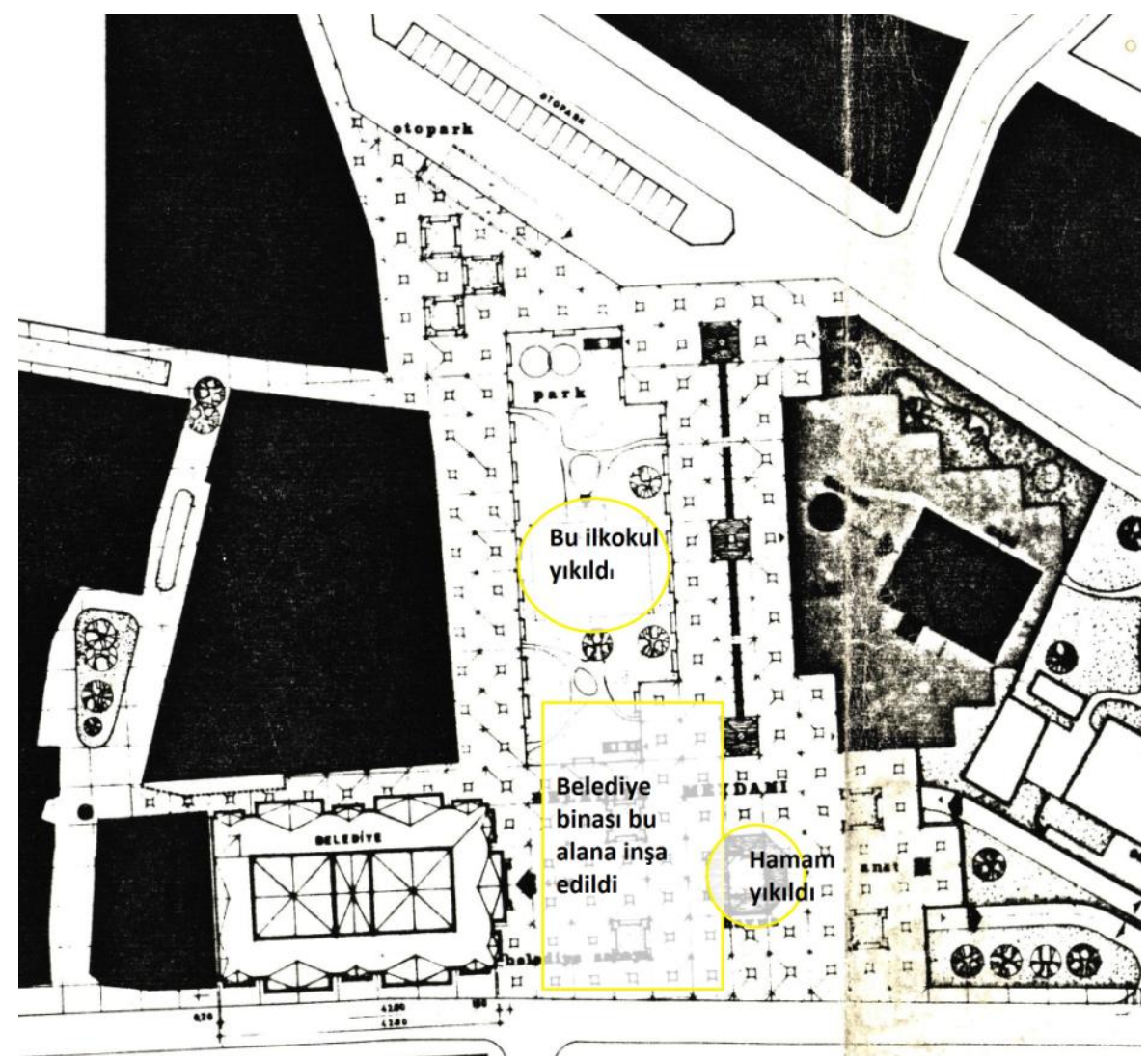

Resim 5. Belediye binası vaziyet planı (Çorlu Belediye Arşivi). 


\section{Mekân ve plan kurgusu}

Belediye binası çok katlı tekil modern yapısı, betonarme yapım tekniği, kübik formu, 1zgara cephesi, monoblok görünümü, geleneksel çatı ve bezemelerden yoksun mimarisiyle, modern mimarlığın özelliklerini yansıtır. Bozdoğan'ın (2002) modern mimarlık öğretisi için belirtiği özelliklerle bire bir örtüşmektedir. Kendisi bu özelliklerin, betonarme kullanımı, kübik formların, geometrik şekillerin ve kartezyen ızgaraların öne çıkmasının hepsinden önemlisi bezemenin, stilistik motiflerin, geleneksel çatıların ve tezyini detayların bulunmayışının 20.yy estetik bilinci içinde tanımlı özellikler olduğunu ifade eder [5].

Bina iki aynı dikdörtgen kütlenin, ortak iki merdiven ve asansör bölümünün (çekirdek kısmının) (Resim 6) biraraya gelmesiyle, doğu/batı aksında yerleştirilmiştir. Kuzeydeki giriş bölümünün önünde geniş bir meydan yer almaktadır. Doğudan da projede bir giriş verilmiş, fakat bu giriş gerçekleştirilmemiştir. Proje iki buçuk kat bodrum, zemin kat ve dört normal kat olarak hazırlanmıştır (Resim 7). Ancak birinci bodrum katı (çarşı katı ve otopark) olarak tasarlansa da zeminde su çıkmasından dolayı bu katın zemin üzerine verilmesine karar verilmiş ve binabir buçuk bodrum, zemin ve beş normal kat olarak tamamlanmıştır. En alt bodrum katta, kütlenin batı aksındaki, sadece yarısı, tiyatro sahne ve depolar olarak tasarlanmiştir. Üst katında ise bu tiyatronun, sahnesi ve fuaye katı tüm binanın bodrum katı kullanılarak yerleştirilmiştir. Bu tiyatro sahnesi bugün Çorlu'da bir çok tiyatroların ve gösterilerin yapıldığı mekân olarak kullanılır. Diğer katlar ise, giriş katı, başkanlık katı, düğün salonu -fen işleri katı, yemekhane-su otobüs işleri katı ve şehir kulübü-hukuk işleri katı olarak düzenlenmiştir.
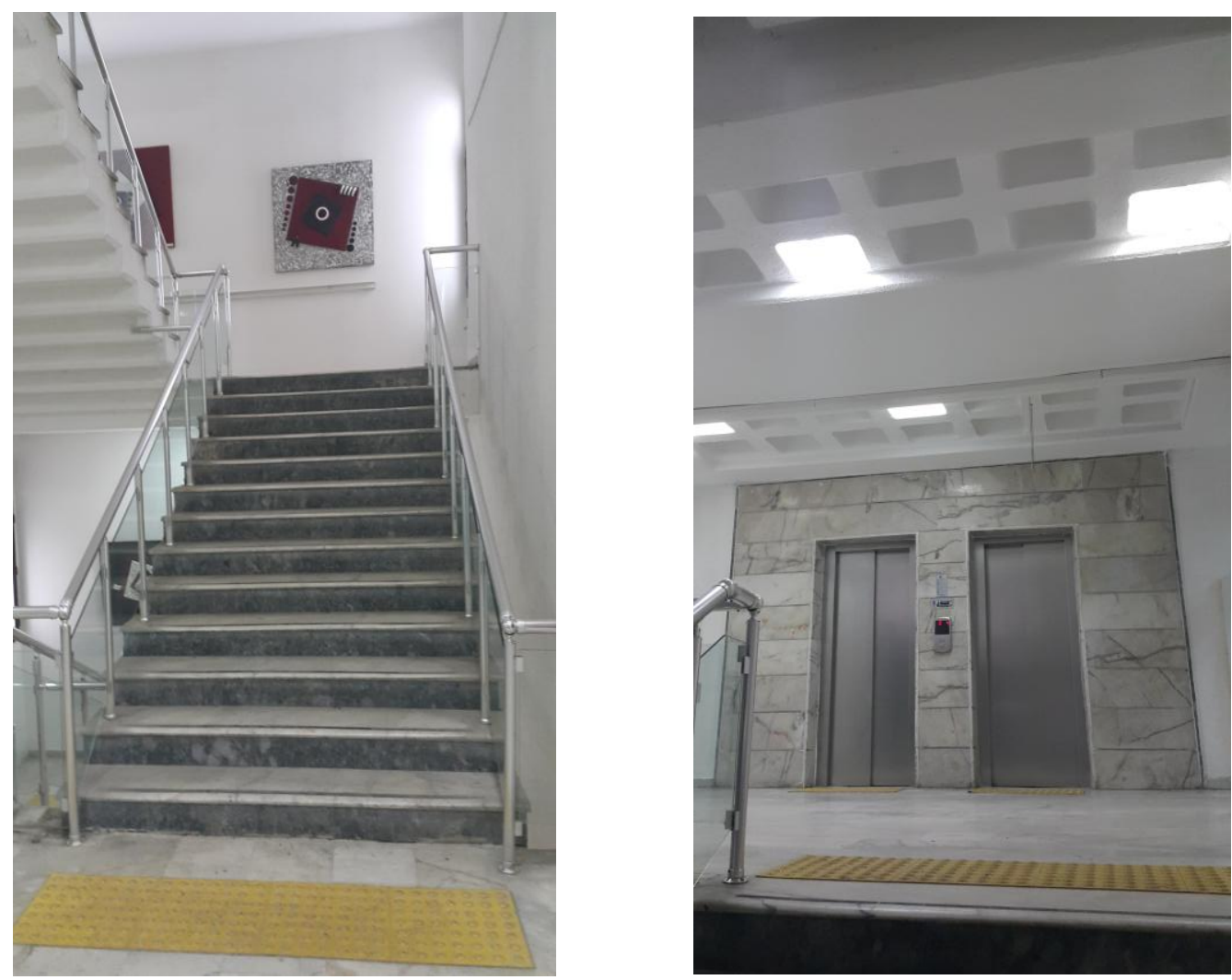

Resim 6. Yapının merdiven ve asansörü (Yazar Arşivi). 

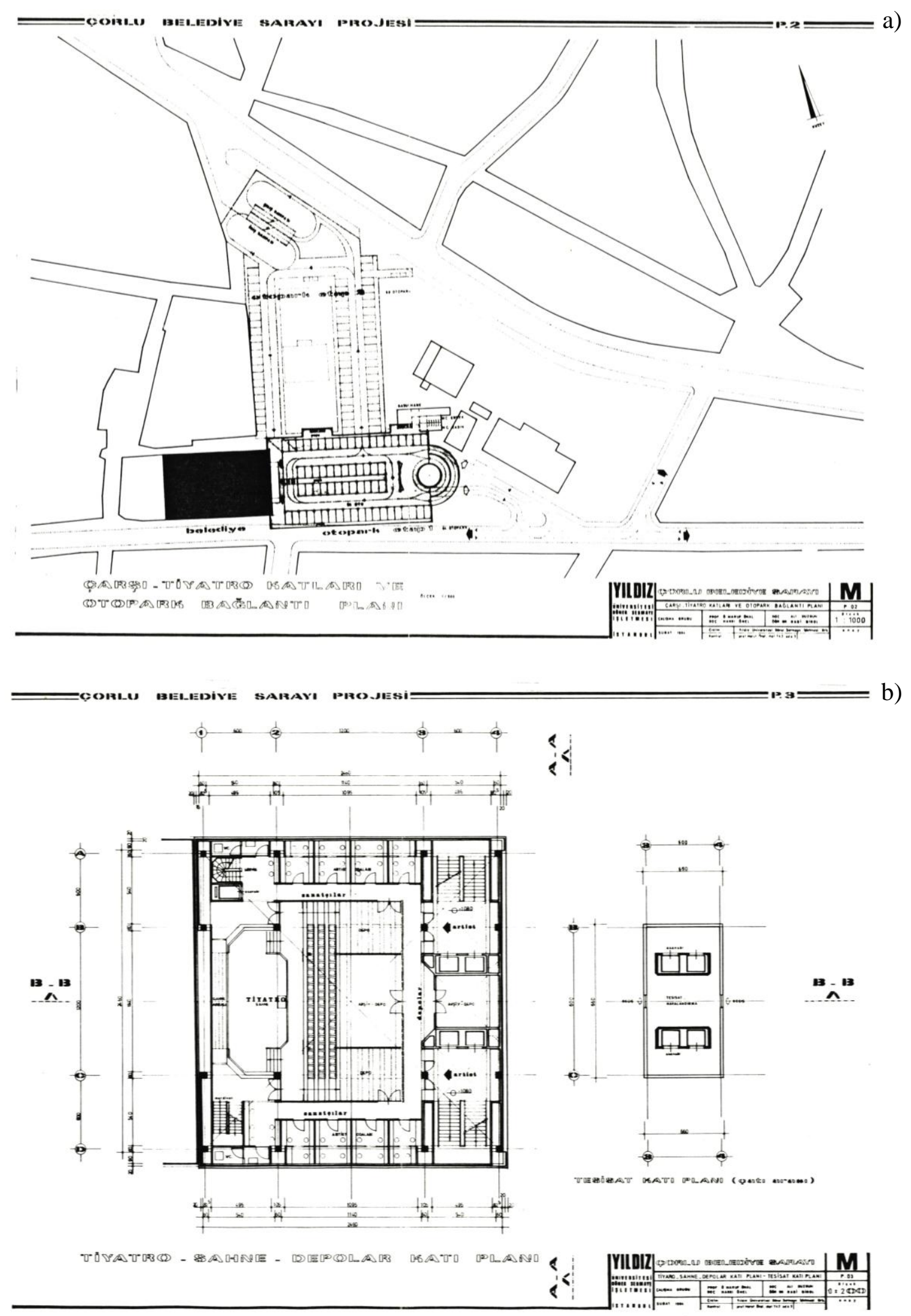

Resim 7. a) Belediye binası vaziyet planı ve b) Tiyatro-sahne depolar kat planı. 


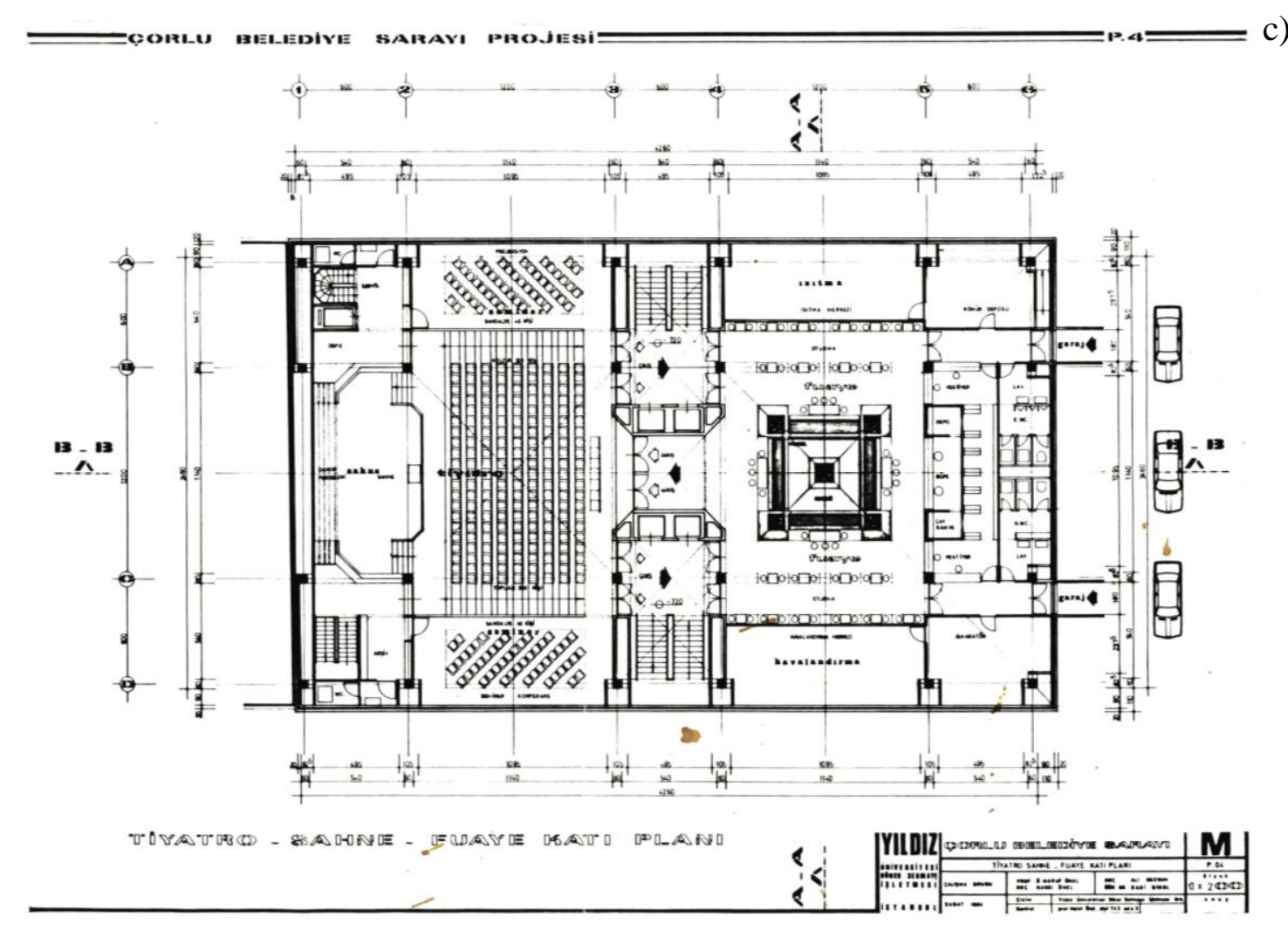

d)

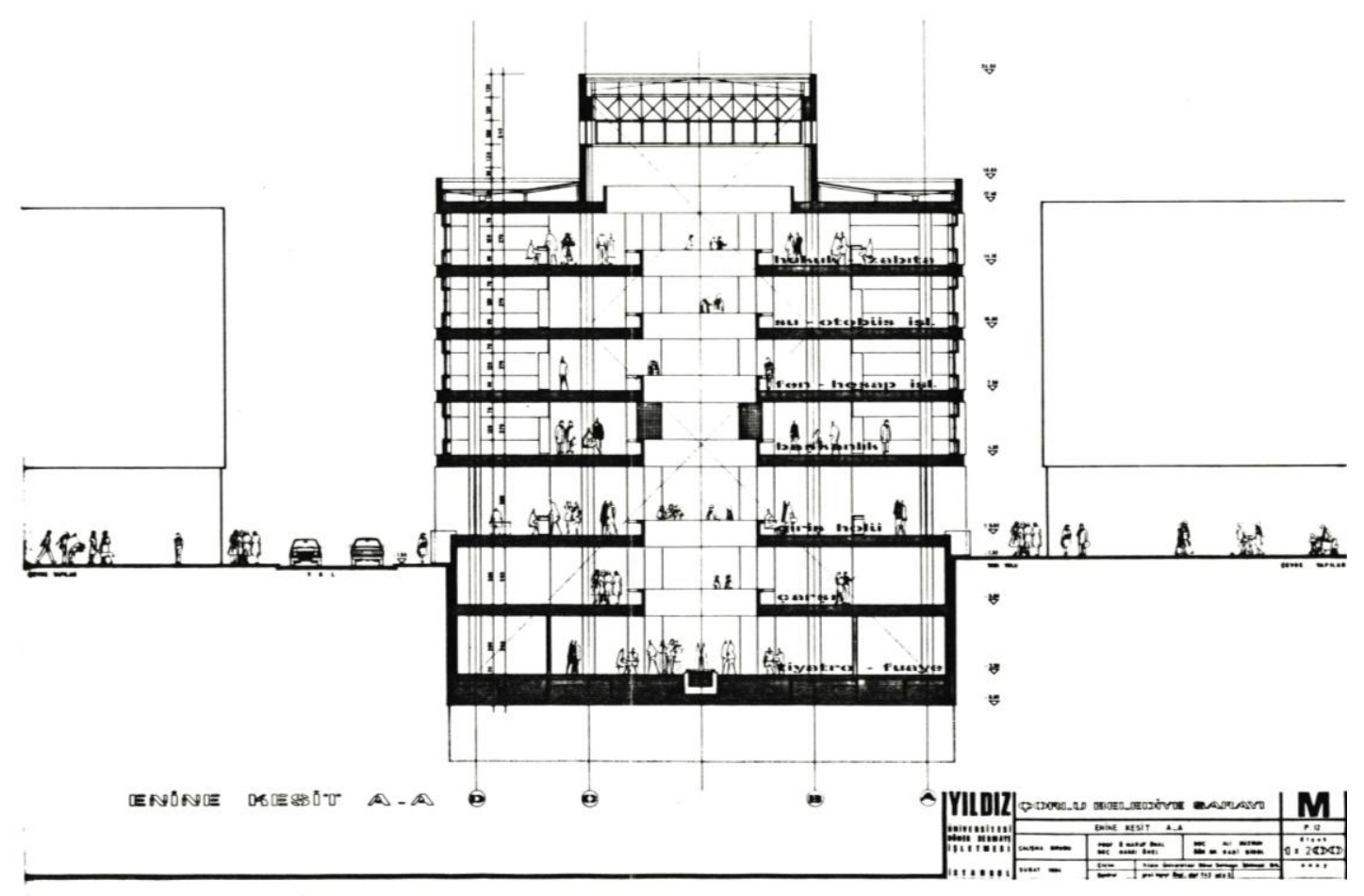

Resim 7. c) Tiyatro sahne fuaye kat planı ve d) Enine (A-A) kesiti 


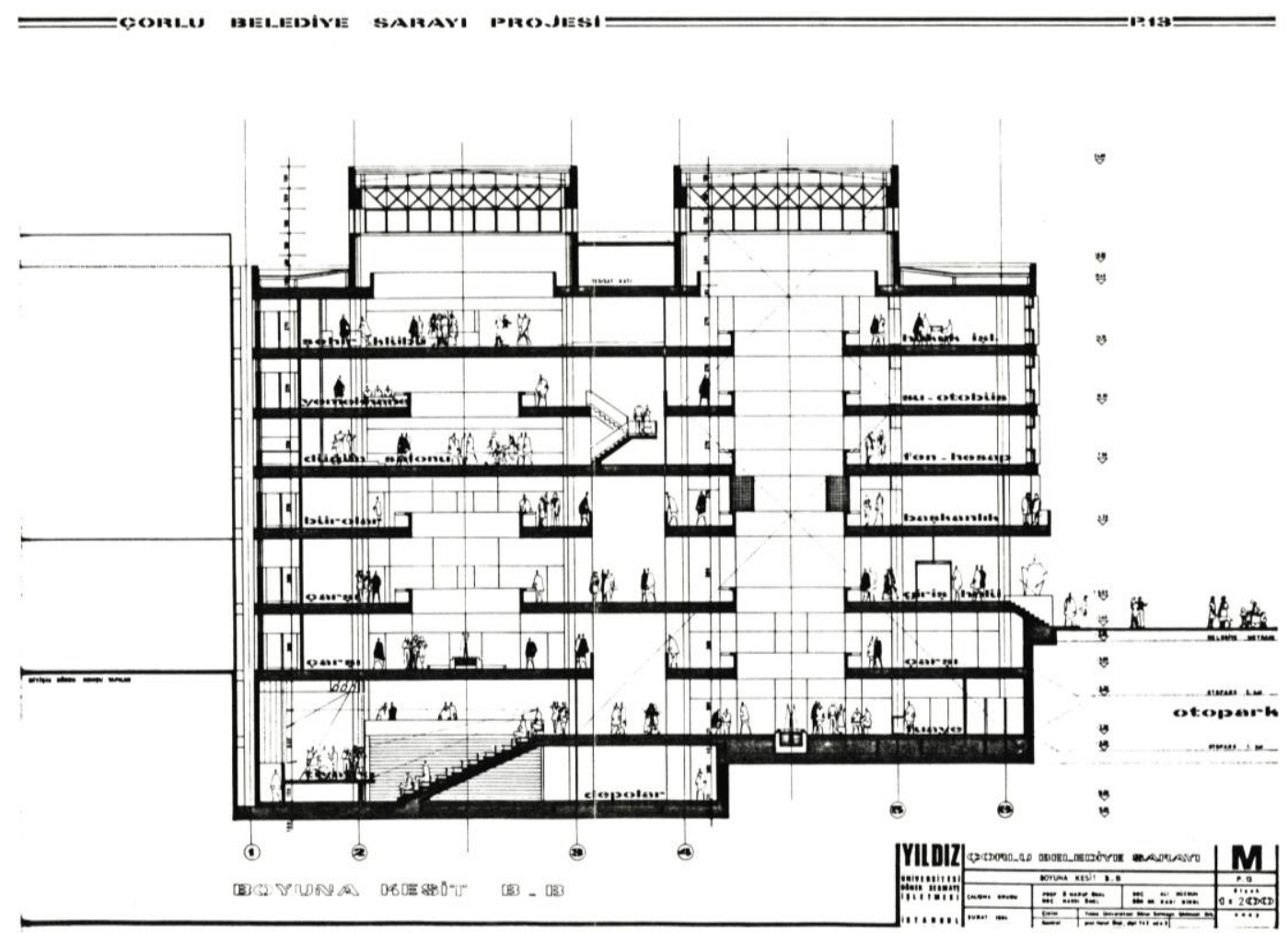

e)

\section{Resim 7. e) Boyuna (B-B) kesiti.}

Mimari açıdan yapıda her türlü ayrıntının düşünülmüş olması sayesinde, sadece dış cephe değil, plan ve iç mekânda da modern bir dil etkindir. Giriş katında, her iki blokta da geniş birer atriyum dikkati çeker. Bina plan tasarımında, masif çerçeve ve kısmen en dikkat çekici ve tartışmalı özelliği olan "atriyum"un kullanılması, bina iç mekânının görselliğini arttırmıştır. Bu mekân binanın nefes alacağı, akciğeri gibi davranır. Beklenmedik keyifli çalışma şartlarını iletmek üzere tasarlanan bu mekân, mimarlar tarafından örneklendirilen bir sosyal etkileşim idealini de tarifler. (Resim 8)

Belediye binasının kütlesi, temelde asal geometrik bir biçim olan iki kare prizmanın yanyana gelmesiyle oluşur. Bu yapı (planda $24.60 \mathrm{mx} 42.69 \mathrm{~m}$ ) planında basit ve yaygın bir tip olan atriyum etrafında simetrik olarak yerleştirilen büroların doğrusal bir şekilde biraraya getirilmesinden meydana gelmiştir. Yapının hem düzgün ve statik kütlesinde, hem de cephe ve planlarda sedelik ve yalınlık ön plandadır. 

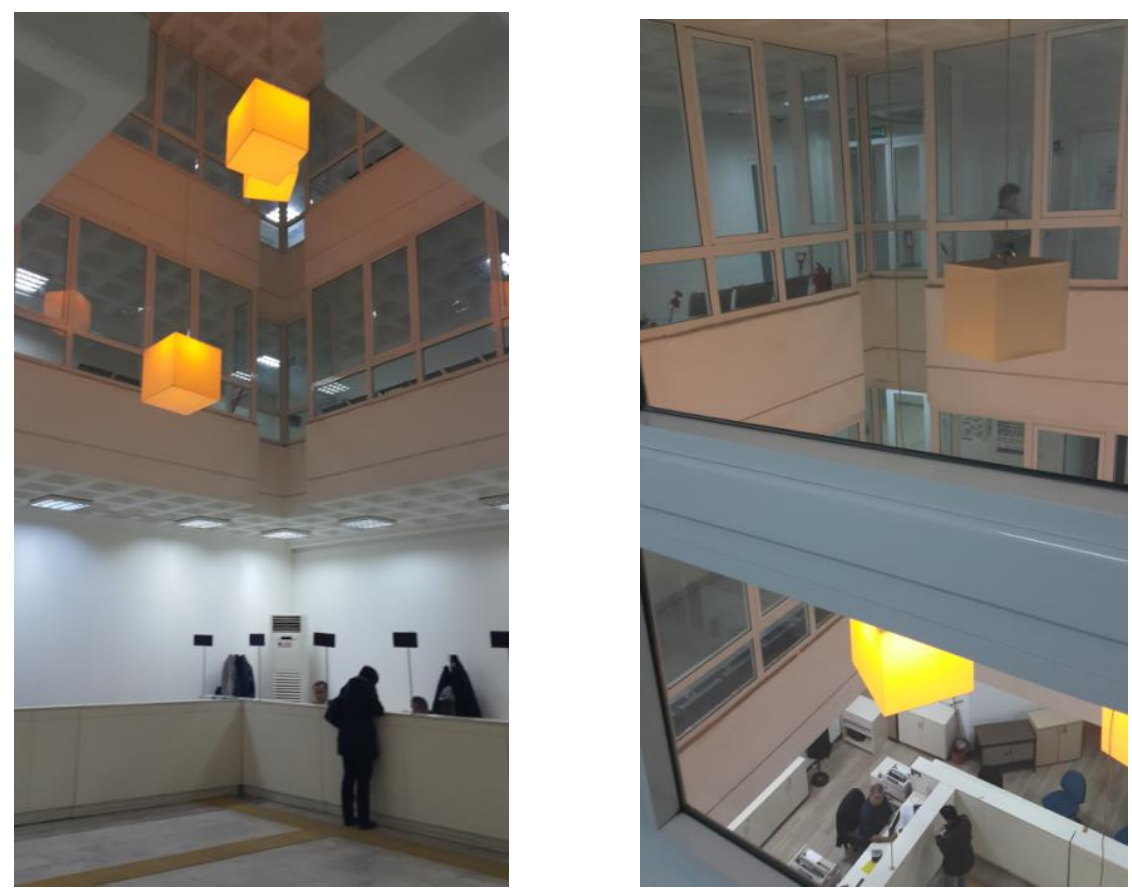

Resim 8. Yapıda yer alan atriyum (Yazar Arşivi).

\section{Dış mekân ve cepheler}

Kentsel mekânlar, kentin tanımında, kullanıcıların kültürel kimlikleri, kişisel gelişimleri ve insanların birbirleriyle etkileşimleri sonucu kentli olma deneyimini elde etmesini sağlayan mekânlar olarak karşımıza çıkar [6]. Çorlu belediye binasının önünde yer alan meydan da, bu kentsel mekânlardan birine örnek olmuştur. Bugün "Cumhuriyet meydanı" olarak adlandırılan, kent için çok önemli bir mekânı işaret eder. Çünkü kent içinde yapılan tüm gösteri, tören ve toplumsal hareketlerin bu belediye/kent meydanın da gerçekleştirildiği görülür. Kentte ortak bir bellek oluşumunu sağlayan bu mekân, zamanla, halkın biraraya gelip, ortak hikayelerin aktarıldığı, dolayısıyla kamusal alanın inşa edildiği bir mekân haline gelmiştir. Kuşkusuz ki, kentli belleğinin ve kimliğinin oluşumuna katkıda bulunmuş ve bu kimliğin dönüşümünde rol oynamıştır. Belediye meydanı artık kolektif bellekte bir derinliğe sahip olurken, son 30 yıllık dönemde Çorlu'da gerçekleşmiş tüm kapsamlı sosyal ve kamusal hareketlerin adresi olmuştur.

Cephelerde ise, kat aralarında dışa doğru çıkmalar, düzenlemenin iki boyutlu bir tasarım olmanın ötesine taşındığını göstermektedir. Cephe kuruluşundaki en önemli özellik, her pencerenin altında ve üstünde kare ve kenarları yivlerle belirlenmiş geometrilerin, tüm cephe boyunca dikey doğrultuda devam etmesidir. Mimar, burada pencerelerin devam edildiği etkisi vererek cephede bir bütünsellik ve devamlılık ilişkisini hem özgün hem de modernizme özgü bir biçimde kurgular (Resim 9).

Cephede en dikkat çekici ögelerden biri, giriş bölümünün üzerinde yer alan ve tam meydana hakim olan "balkon"dur. Başkanları veya liderlerin çeşitli konuşmalarını bu balkondan yaparak halka hitap edecekleri düşünülerek bir hitap balkonu şeklinde yapılmış olabilir. Çünkü 30'lu yıllarda Türkiye'de kurulan Halkevi binalarında sıklıkla rastladığımız bu hitap balkonu, aynı düşünce doğrultusunda tasarlanmış olabilir. Kadıköy Halkevinde yer alan balkon için mimar Rüknettin Güney (1938) şunları söyler; 


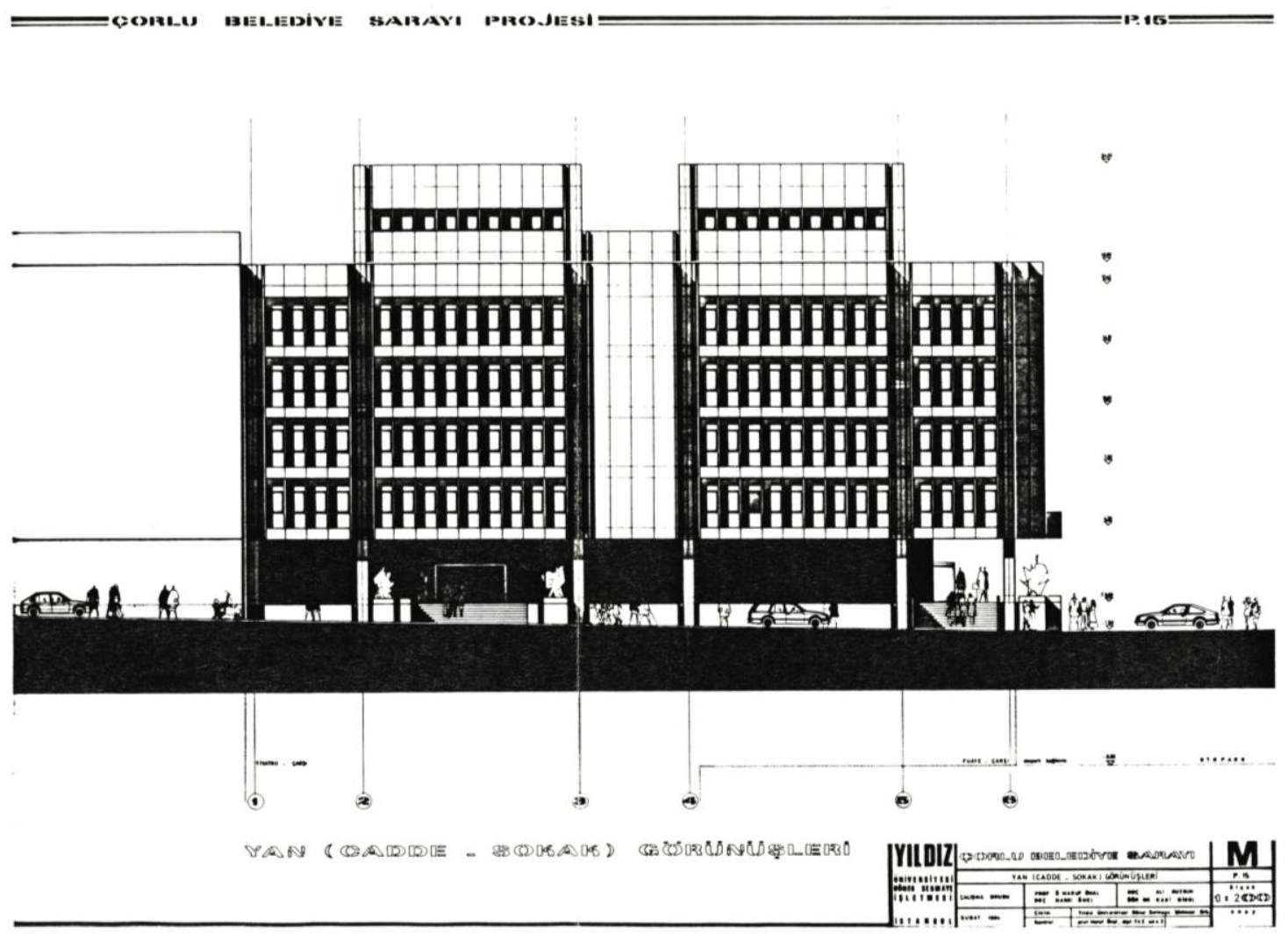

b)

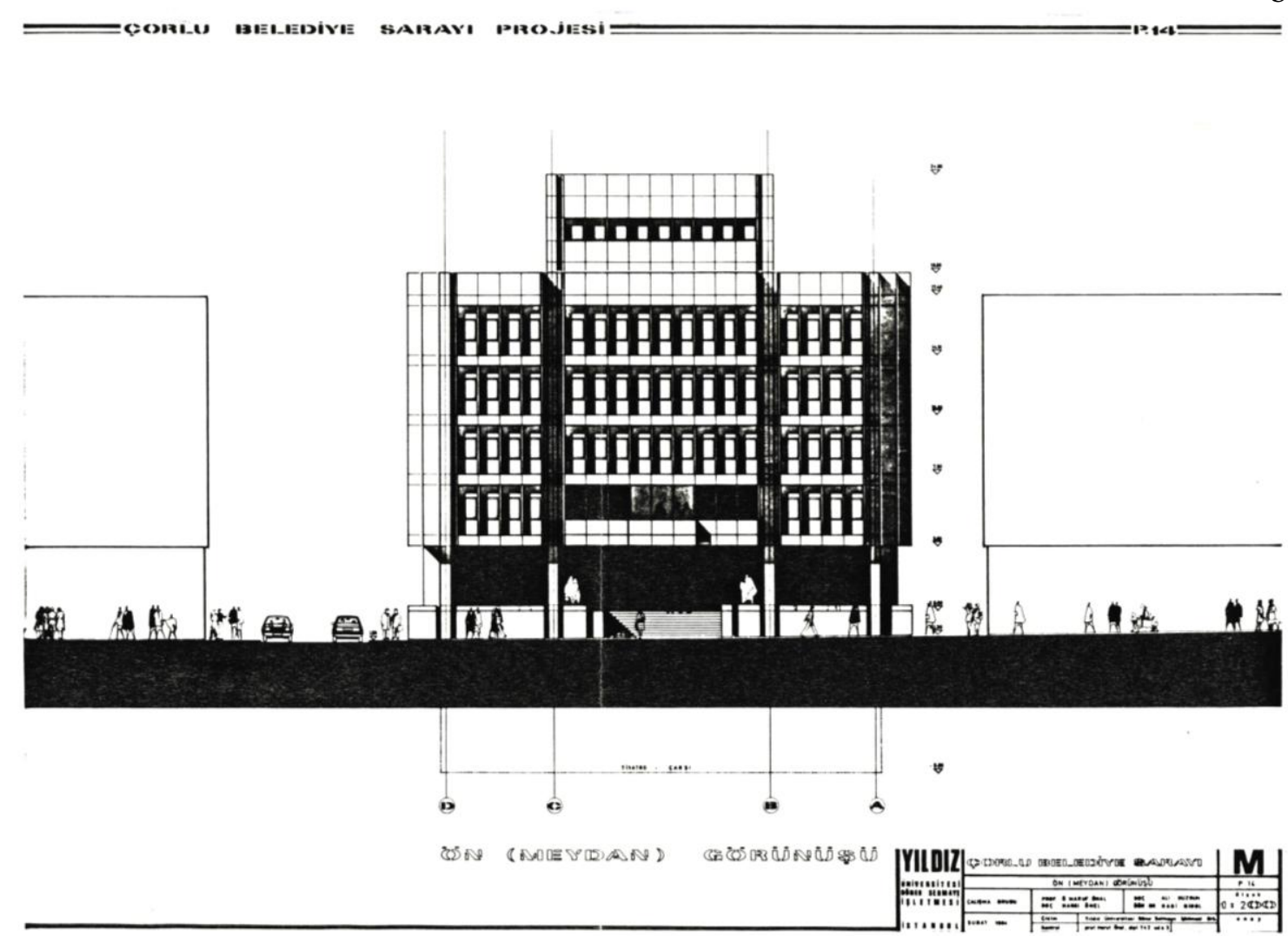

Resim 9. a) Belediye binası yan (cadde) görünüşü ve b) Belediye binası ön (meydan) görünüşü. 
"Bu avluda şenlik günleri bir kısım halk da toplanarak balkondan söylenecek nutukları dinleyebilir. Parti başkanı da odasındaki balkondan sokaktan geçen halk kitlesine hitap edebilir". [7] Cephede de fazla dikkat çekmeyen fakat oldukça mütevazi bir şekilde binayla dengeli bir şekilde koyulmuştur.

\section{Değerlendirme}

Çorlu belediye sarayı projesinde, daha önceki çalışmaları ve mimarlığa katkıları incelendiğinde mimar Maruf Önal'ın etkileri göze çarpar. Maruf Önal 2000 yılı Ulusal Mimarlık Ödülleri'nde “Sinan Ödülü”ne layık görülmüş ve şu sözlerle anılmıştır: "Meslek yaşamında ulusal mimarlığımıza eserleri yoluyla yaptığı katkılar, yarattığı en mütevazı yapılarda dahi gösterdiği duyarlılık ve yakaladığı kalıcılık, uzun süren eğitimci yaşamı süresince kuşaklararası iletişımin sağlanmasına katkıları, mimarlık mesleğinin örgütlenme ve kurumlaşmasına yaptığ bir referans oluşturan Prof. Maruf Önal...." [8]. Bu yazıda, kendisinin "mütevazı bir yapıda gösterdiği duyarlılık ve yakaladığı kalıcılık" etkilerinin görüldüğü bir yapı olan Çorlu belediye sarayı yapısı tanıtılmaya çalışılmıştır. Kendisinin, diğer çalışma arkadaşlarıyla birlikte, daha önceki çalışmalarındaki yaklaşımları da dikkate alınarak modernist bir tavır içerisinde bu yapıyı da tasarladığı görülür.

Sonuç olarak, Önal ve arkadaşlarının bu yazıda ele alınan Belediye sarayı yapısı, 1980’lerde dahi mimarlıkta modern dilin devam ettiğini gösterir niteliktedir. Özellikle tüm cephelerdeki pencere kenarları derin fuga ile derinleștirilerek, kat silme ve geometrileri dört katta devam ettirilerek, yapının plastiğinde ilginç bir detay olarak kat seviyelerini ortadan kaldırır. Bu baskın plastik arayış, son katta arınmış düz bir satıhla sonlanır.Ayrıca tekil modern yapıların çok katlı, ızara cepheli monoblok mimarisinin yorumlanması, bu yapıda dikkat çeker. Yapının mekân kurgusunda da hem rasyonalizm ve işlevselcilik ilkeleri ön plana çıkarken, geometrik hacimlerinin ahenkli bir kompozisyonu da vardır (Resim 10).

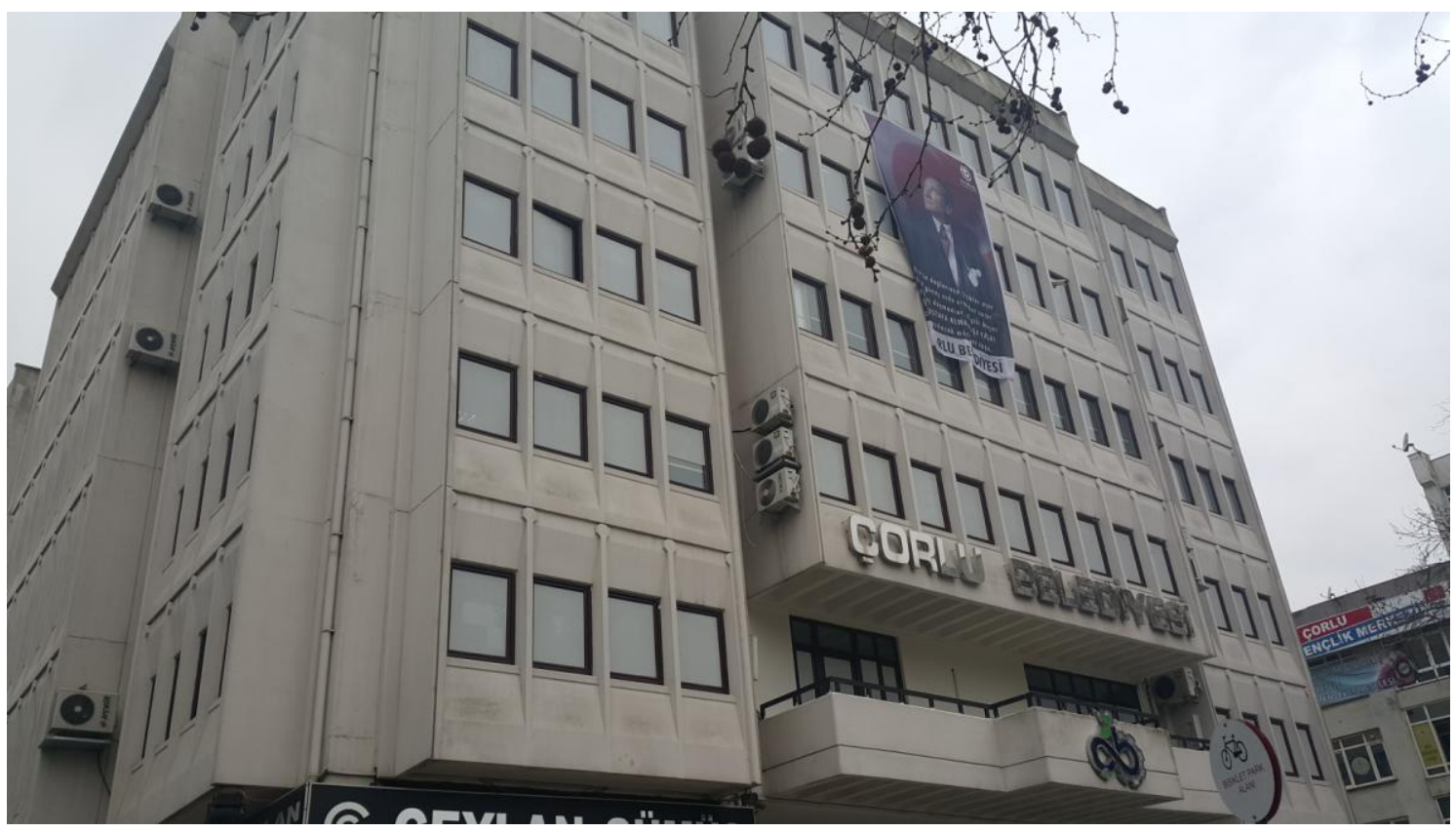

Resim 10. Ön görünüş (Yazar Arşivi). 
Maruf Önal'ın ilk ürünü olan Beşiktaş'taki 1943 yılında yaptığı Dr. Belen Evi için Doğan Hasol şöyle der: "Alçakgönüllü, akılcı, çevreye saygıll, oranları doğru kurulmuş bir yapı". [9] Bu değerlendirme yıllar sonra yaptığı Çorlu belediye Sarayı için de geçerlidir. Boş bir alanda bile olsa sade ve yalın cephesi, çevreye saygılı duruşu ve oranların dikkatli kullanımı dikkat çekicidir.

\section{Teșekkür}

$\mathrm{Bu}$ makalede fotoğraflara ve bilgilere ulaşmamda yardımcı olan İnş. Müh. Kerem Savaş'a çok teşekkür ederim.

\section{Kaynaklar}

[1] Altan E.E., Cumhuriyet'in mekânları/zamanları/ insanları: Mimarlık tarih yazımı üzerine değerlendirme, Altan E. E. ve İmamoğlu, B. (derleyenler), Ankara: *Dipnot Yayınları, ODTÜ MF, 11-24, (2010).

[2] Uz, F., Mekân-politik bir söylem olarak nostalji, Dosya 33, TMOBB Mimarlar Odası Ankara Şubesi, 201471, 79, (2014).

[3] Anonim, Trakya'nın incisi altın topraklar diyarı Çorlu, Çorlu Belediyesi Kültür Yayınları, Çorlu, (2006).

[4] Eserleri - Maruf ÖNAL (1918-2010), www.marufonal.com/eserleri.php. (erişim tarihi 15.06.2017).

[5] Bozdoğan, S., Modernizm ve ulusun inşası: Erken cumhuriyet Türkiye'sinde mimari kültür, (çev.) Tuncay Birkan, Metis Yayınları, İstanbul., (2002).

[6] İnceoğlu, M., Aytuğ, A., Kentsel mekânda kalite kavramı, Megaron Dergisi, 4, 3, 131, (2009).

[7] Güney, R., Kadıköy Halkevi proje müsabakası, Arkitekt, 2, 43-56, (1938).

[8] Birol, R., Anma, Mimarlık Dergisi, 357, (2011).

[9] Hasol, D., Örnek insan, usta mimar Maruf Önal'ın ardından, Yapı Dergisi, 349, (2010). 